\title{
Differential expression of angiotensin II type 1 and type 2 receptors at the maternal-fetal interface: potential roles in early placental development
}

\author{
C L Tower, S Lui, N R Charlesworth, S D Smith, J D Aplin and R L Jones \\ Maternal and Fetal Health Research Group, Manchester Academic Health Science Centre, St Mary's Hospital, \\ University of Manchester, Oxford Road, Manchester M13 9WL, UK
}

Correspondence should be addressed to R L Jones; Email: rebecca.lee.jones@manchester.ac.uk

\begin{abstract}
Angiotensin II (Ang II) is locally generated in the placenta and regulates syncytial transport, vascular contractility and trophoblast invasion. It acts through two receptor subtypes, AGTR1 and AGTR2 (AT1 and AT2), which typically mediate antagonising actions. The objectives of this study are to characterise the cellular distribution of AGTR1 and AGTR2 at the maternal-fetal interface and explore the effects on cytotrophoblast turnover. Low levels of AGTR2 mRNA were detected in first trimester placental homogenates using real-time PCR. Immunohistochemistry using polyclonal antibodies against AGTR1 and AGTR2 detected the receptors in first trimester placenta, decidua basalis and villous tip outgrowths in culture. Serial staining with cytokeratin-7 was used to identify extravillous trophoblasts (EVTs). AGTR1 was found in the syncytiotrophoblast microvillous membrane, in a subpopulation of villous cytotrophoblasts, and in Hofbauer cells. AGTR1 was strongly upregulated in cytotrophoblasts in cell columns and villous tip outgrowths, but was absent in interstitial and endovascular EVTs within the decidua. AGTR2 immunostaining was present in Hofbauer cells and villous cytotrophoblasts, but was absent from syncytiotrophoblast. Faint staining was detected in cell column cytotrophoblasts and villous outgrowths, but not in EVTs within the decidua. Both receptors were detected in placental homogenates by western blotting. Ang II significantly increased proliferation of cytotrophoblasts in both villous explants and villous tip outgrowths, but did not affect apoptosis. Blockade of AGTR1 and AGTR2 together abrogated this effect. This study shows specific expression patterns for AGTR1 and AGTR2 in distinct trophoblast populations at the maternal-fetal interface and suggests that Ang II plays a role in placental development and generation of EVTs.

Reproduction (2010) 140 931-942
\end{abstract}

\section{Introduction}

Normal development of the villous placenta in early pregnancy, and coincident colonisation of the maternal decidua by extravillous trophoblasts (EVTs), is essential to a healthy pregnancy. Insufficient growth and development of the villous tree reduces the gaseous and nutrient transfer capacity of the placenta and can lead to fetal growth restriction (FGR), while shallow EVT invasion and impaired remodelling of uterine spiral arteries predispose to pre-eclampsia and FGR. Angiotensin II (Ang II), the main effector molecule of the renin-angiotensin system, is locally generated in the placenta (Hosokawa et al. 1985, Cooper et al. 1999) and decidua (Shaw et al. 1989), suggesting actions in regulating placental development. Indeed, many of the well-known actions of Ang II, including regulation of vascular contractility, osmoregulation (Peach 1981), cellular proliferation (Dinh et al. 2001), angiogenesis (Le Noble et al. 1991) and apoptosis (Yamada et al. 1996), are key processes for placental development and function.

Recent studies provide evidence for an important regulatory role for Ang II in trophoblast invasion during early placentation. In vitro studies using a transformed cytotrophoblast cell line (HTR-8/SVneo) demonstrated a potent inhibition of invasive potential, which is abrogated by selective inhibition of type 1 (AGTR1, AT1) receptor signalling (Xia et al. 2002). The physiological significance of this result was supported by a recent report demonstrating Ang II stimulates proliferation, but inhibits differentiation, of cytotrophoblast cells from first trimester villous tip outgrowths in culture (Araki-Taguchi et al. 2008). Ang II is therefore an attractive candidate for mediating the shallow decidual invasion and impaired vascular remodelling in pre-eclampsia and FGR. Greater understanding of the signalling pathways used during vascular remodelling is essential to delineate Ang II actions in regulating EVT invasion in vivo. 
In humans, Ang II actions are mediated through two receptor subtypes, AGTR1 and AGTR2 (AT1 and AT2) receptors, with the AGTR2 receptor generally opposing the actions of AGTR1 (De Gasparo et al. 2000). AGTR1 expression has been demonstrated in villous placenta throughout gestation, localised to syncytiotrophoblast and cytotrophoblast, Hofbauer cells and peri-vascular cells (Li et al. 1998, Cooper et al. 1999, Williams et al. 2010). A low degree of AGTR2-specific binding of radiolabelled Ang II in placental homogenates provided evidence for low expression of the receptor ( $\mathrm{Li}$ et al. 1998), but studies using conventional RT-PCR have failed to confirm this finding (Cooper et al. 1999). A recent study has reported AGTR2 mRNA expression in placental homogenates using real-time PCR and protein expression by immunohistochemistry (Williams et al. 2010).

Despite evidence suggesting a role for both the receptors in the origins of pre-eclampsia and FGR (Plummer et al. 2004, Tower et al. 2006, Xia et al. 2007), comprehensive localisation studies of the AGTR1 and AGTR2 receptors in human placental EVT populations during early pregnancy have not been conducted. Interactions between AGTR1 and AGTR2 have been previously described, through the formation of heterodimers (AbdAlla et al. 2001) and the interaction between the two receptors in other tissues is antagonistic in terms of both opposing function and cellular signalling (Dinh et al. 2001). Therefore, determining the balance and inter-relationships between AGTR1 and AGTR2 in distinct villous and extravillous trophoblast populations at the maternal-fetal interface is critical to understand their potential functions in normal and pathological pregnancies.

The objectives of this study are a) to confirm the presence of the AGTR2 receptor in first trimester human placenta using real-time PCR techniques and immunohistochemistry, b) to conduct detailed localisation studies of both AGTR1 and AGTR2 receptors at the early pregnancy maternal-fetal interface and c) to investigate the effect of Ang II on villous and extravillous trophoblast cell turnover.

\section{Results}

\section{AGTR2 mRNA expression by first trimester placenta}

Real-time PCR using SYBR green identified the presence of AGTR2 mRNA in ten first trimester placental homogenates $(n=15)$. Although quantification was not conducted, fluorescence levels were low. The cycle threshold $\left(C_{\mathrm{t}}\right)$ for detection of AGTR2 mRNA in myometrial samples was typically 24-26, but that for placenta was 30-32 (Fig. 1A and B). PCR products were subsequently subjected to agarose gel electrophoresis, demonstrating that, as suspected, most placental samples $(n=11)$ had expression levels too low for detection by ethidium bromide (Fig. 1C).
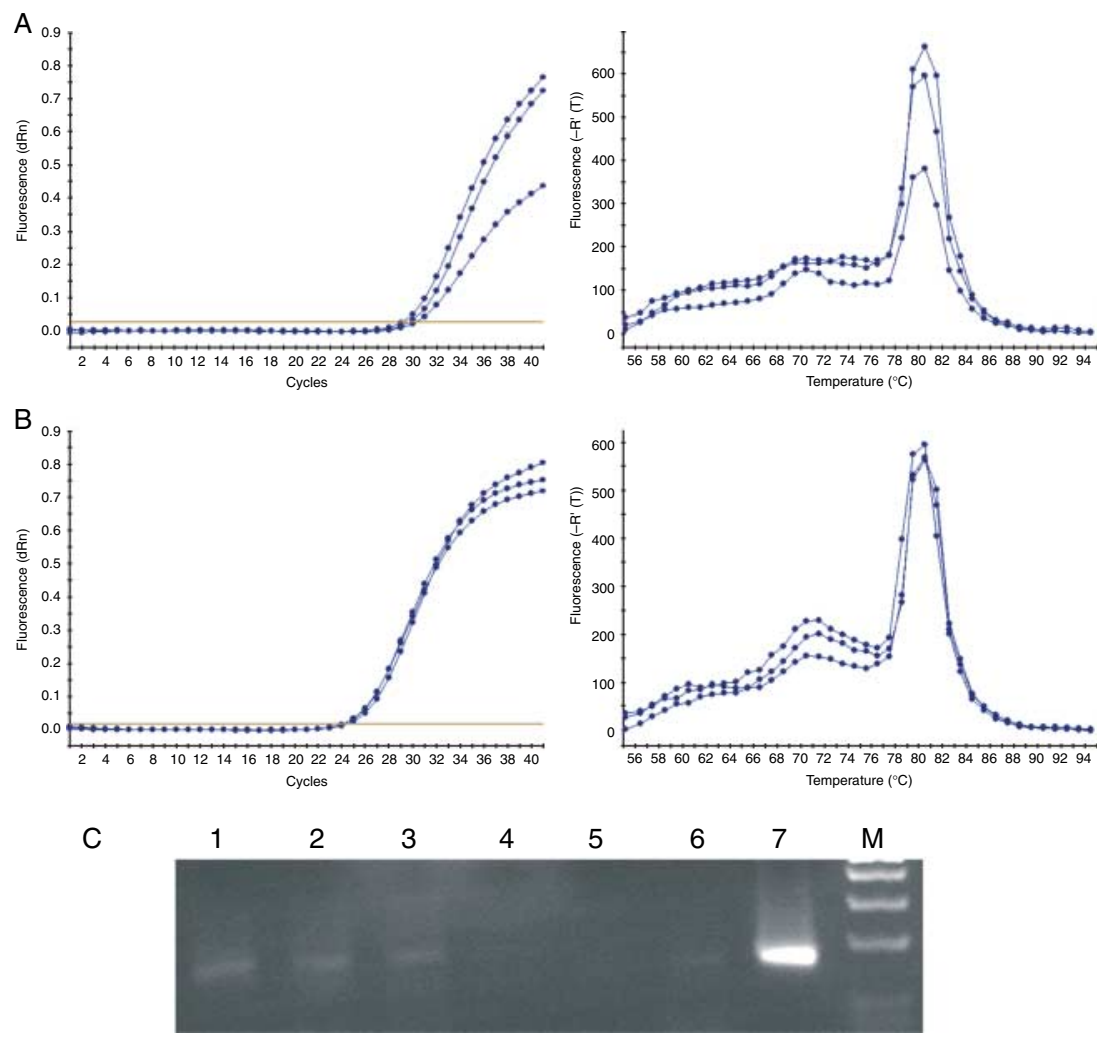

Figure 1 AGTR2 mRNA expression in first trimester human placenta. Representative amplification and dissociation curves from real-time PCR analysis of AGTR2 mRNA expression in (A) placenta and (B) myometrium. (C) Gel electrophoresis of AGTR2 PCR products (176 bp). Lanes $1-3,5$ and 6 , first trimester placenta; lane 4, negative control; lane 7, myometrium positive control; lane 8, DNA ladder. 


\section{Immunolocalisation of AGTR1 and AGTR2}

Immunohistochemical protocols were optimised on formalin-fixed paraffin tissue sections enabling clear delineation of distinct cytotrophoblast cell subpopulations. The specificity of immunostaining was confirmed by the inclusion of adult mouse (for AGTR1) and fetal (for AGTR2) kidney sections, demonstrating specific localisation patterns in accordance with previous publications (Fig. 2A and B; Ozono et al. 1997, Miyata et al. 1999). Pre-adsorption of both antibodies with the appropriate peptide resulted in a complete absence of staining in both placental and kidney tissues (Figs 2C, D, H, L and 3C).

\section{AGTR1 localisation}

In villous placenta, AGTR1 was localised specifically to the apical microvillous membrane of syncytiotrophoblast, with fainter staining in a subpopulation ( $\sim 20-30 \%)$ of villous cytotrophoblasts (Fig. 2E). Hofbauer cells in the villous core exhibited intense membrane immunostaining (Fig. 2F). No staining was detected in vascular endothelial cells of capillaries and larger central vessels (Fig. 2G).

In contrast to the relatively weak staining in villous cytotrophoblasts, AGTR1 was strongly upregulated in cytotrophoblasts in cell columns (Fig. 3A and B), and in those EVTs detaching from the column and entering the

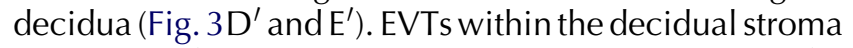
were identified by immunostaining serial sections for cytokeratin-7 (CK-7; Fig. 3F and G). AGTR1 was markedly absent from interstitial EVTs and endovascular/mural
EVTs surrounding and lining decidual vessels (Fig. 3 $\mathrm{F}^{\prime}$ and $G^{\prime}$ ). Decidual stromal and epithelial cells were strongly positive for AGTR1.

\section{AGTR2 localisation}

Unlike AGTR1, AGTR2 immunostaining was absent from the syncytiotrophoblast, but present in the underlying layer of villous cytotrophoblasts (Fig. 2I-K). Hofbauer cells exhibited intense membrane staining, while vascular endothelial cells were negative for AGTR2 (Fig. 2I). Faint heterogeneous immunostaining for AGTR2 was detected in cytotrophoblasts in the cell column (Fig. 4A and B). Decidualised stromal cells were strongly immunopositive for AGTR2, but as for AGTR1, interstitial or endovascular EVTs within the decidua were conspicuous by their lack of staining (Fig. 4C $C^{\prime}$ and $D^{\prime}$ ). Decidual epithelial glands exhibited patchy staining for AGTR2 (Fig. 4C').

\section{Villous tip outgrowths}

EVTs generated by performing outgrowths from villous tips cultured on collagen were strongly and homogeneously positive for AGTR1 (Fig. 5B and D). AGTR2 immunostaining was detected in EVT outgrowths distal to the villous tip (Fig. 5F).

\section{Western blots}

A signal of $44 \mathrm{kDa}$, corresponding to AGTR1 receptor, was detected in 3T3 and SGHPL-4 cells (kindly provided by Prof. Guy Whitley, St George's Hospital Medical
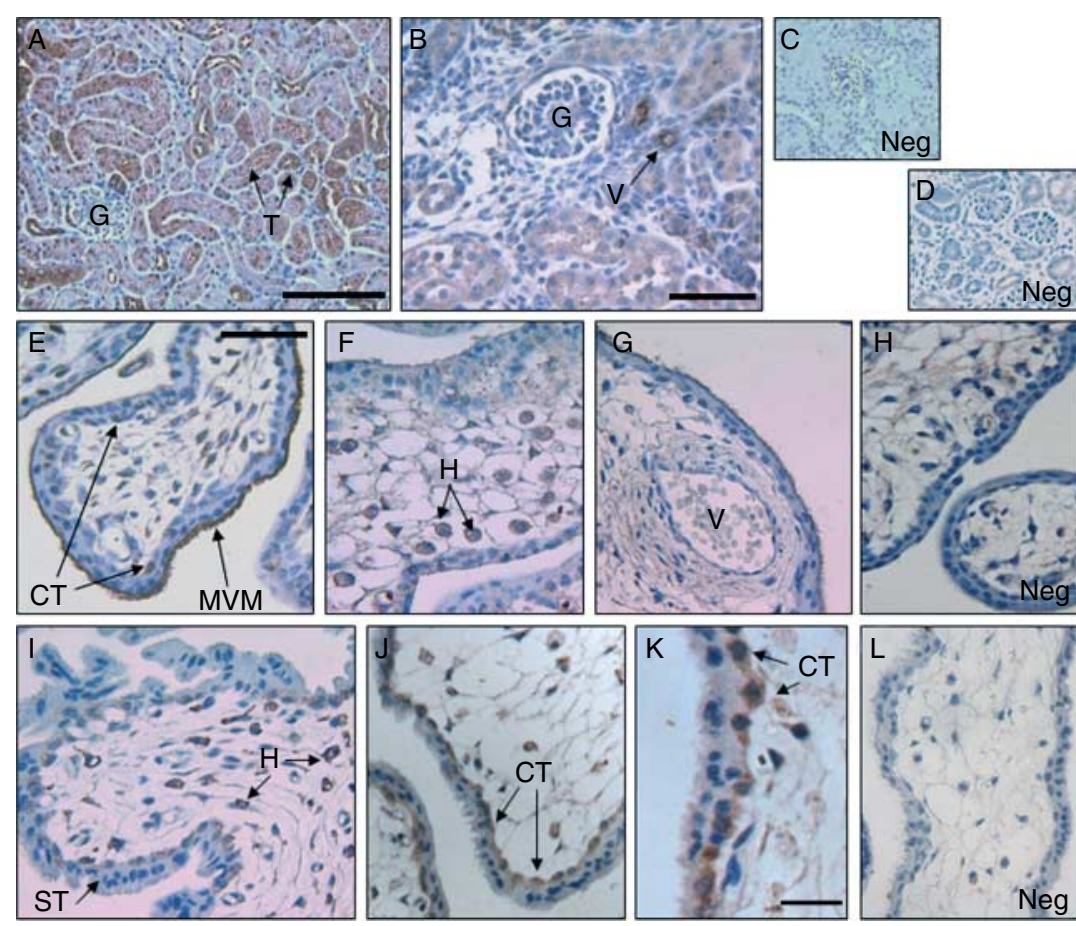

Figure 2 Immunolocalisation of AGTR1 and AGTR2 receptors in first trimester placental villous tissue. (A) AGTR1 immunostaining in adult mouse kidney, (B) AGTR2 immunostaining in fetal mouse kidney (G, glomerulus; $\mathrm{T}$, tubule; $\mathrm{V}$, vessel), (C) absence of immunostaining in adult mouse kidney following pre-adsorption of AGTR1 antibody with $5 \times$ blocking peptide, (D) absence of immunostaining in fetal mouse kidney following pre-adsorption of AGTR2 antibody with $5 \times$ blocking peptide. $(E-H)$ AGTR1 immunohistochemistry of first trimester placenta, showing (E) intense immunoreactivity on the microvillous membrane (MVM) and in occasional villous cytotrophoblast cells (CT), (F) in Hofbauer cells $(H),(G)$ an absence of staining in placental vasculature and $(\mathrm{H})$ when the primary antibody is pre-adsorbed with blocking peptide. (I-L) AGTR2 immunohistochemistry of first trimester placenta, showing (I) an absence of immunostaining in syncytiotrophoblast (ST), but strong staining in Hofbauer and $(\mathrm{J}+\mathrm{K})$ CT cells. (L) No staining was detected following pre-adsorption of AGTR2 antibody with peptide. Scale bar on (A) represents $50 \mu \mathrm{m}$ and refers to all images, except (B) and (K), where scale bars indicate $25 \mu \mathrm{m}$. 

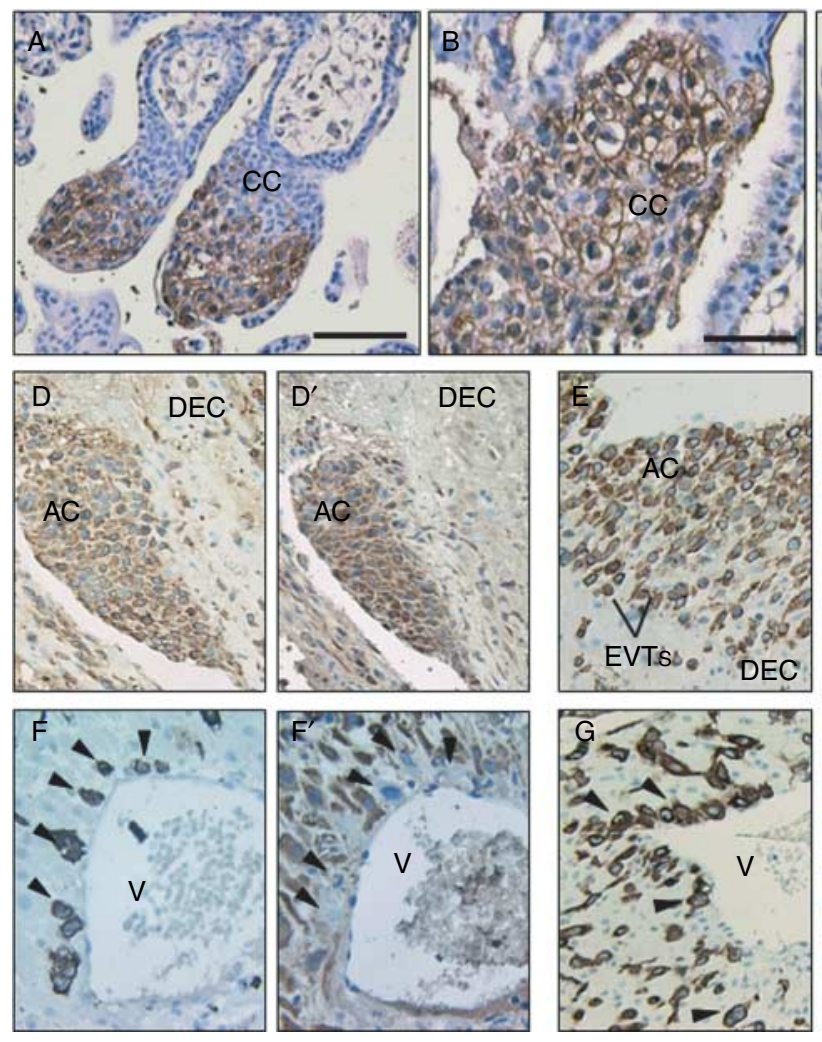
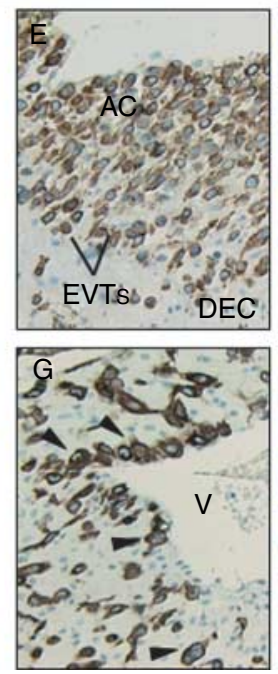
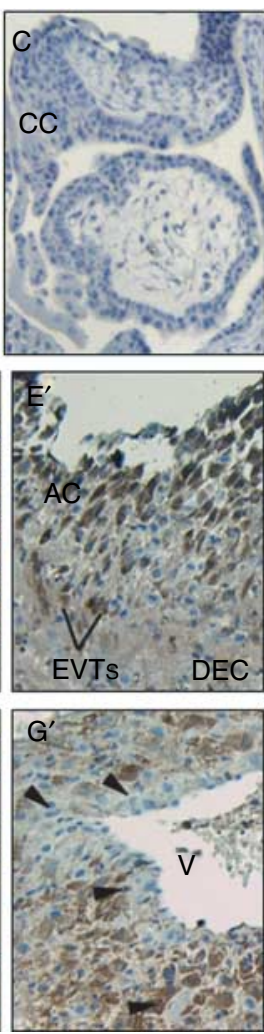

Figure 3 Immunolocalisation of AGTR1 at the maternal-fetal interface in early pregnancy. (A) AGTR1 is upregulated in extravillous trophoblasts (EVTs) in floating cell columns (CC), with cell surface localisation shown in (B) at higher magnification. (C) Negative control showing absence of staining. Staining of serial sections with (D and $E$ ) cytokeratin-7 and ( $\mathrm{D}^{\prime}$ and $\left.\mathrm{E}^{\prime}\right)$ AGTR1 shows expression of AGTR1 in EVTs in anchoring columns and entering the decidua (DEC). Serially stained sections for ( $\mathrm{F}$ and $\mathrm{G}$ ) cytokeratin-7 and ( $\mathrm{F}^{\prime}$ and $\left.\mathrm{G}^{\prime}\right)$ AGTR1 illustrate the absence of AGTR1 expression in interstitial EVTs and those surrounding decidual vessels $(\mathrm{V})$. Representative EVTs in serial sections are indicated by arrowheads. Scale bar on (A) represents $50 \mu \mathrm{m}$ and refers to all images, except (B) where scale bar indicates $25 \mu \mathrm{m}$.
School) and in placental homogenates from the first trimester of pregnancy (7-12 weeks, $n=5)$. Representative blots are shown in Fig. 6A. This band was abolished by pre-adsorption of the AGTR1 antibody with a fivefold excess of blocking peptide, confirming specificity. A strong band of $55 \mathrm{kDa}$ was detected when using the AGTR2 antibody in myometrial homogenate, while no signal was detected in HepG2 cells. A faint band of the same size was detected in placental homogenates (7-12 weeks gestation, $n=5$; Fig. $6 \mathrm{~B}$ ). This band was greatly diminished by peptide pre-adsorption. All membranes were stripped and reprobed for $\beta$-actin for a protein loading control.

\section{Effect of Ang II on villous and extravillous trophoblast cell turnover}

Proliferation of cytotrophoblast cells in villous outgrowths was examined by $\mathrm{BrdU}$ incorporation. Positively stained nuclei were detected in the cytotrophoblasts in the villous tip and in the cell column of the outgrowths (Fig. 7C). Occasional stromal cells were BrdU positive. Substitution of the primary antibody with mouse $\operatorname{lgG}$ resulted in an absence of staining (inset, Fig. 7C). Treatment of villous outgrowths $(n=5-7)$ with Ang II $\left(10^{-7} \mathrm{M}\right)$ significantly stimulated the proliferation of cell column cytotrophoblast cells (Fig. 7A). There was a trend for Ang II $\left(10^{-6} \mathrm{M}\right)$ to stimulate proliferation $(P=0.313)$. This effect was abolished by co-treatment with the AGTR1 and AGTR2 inhibitors CS (candesartan) and PD (PD123319) in combination ( $n=3-6$; Fig. 7B). Co-treatment with CS did not consistently inhibit the stimulatory effect of Ang II. The effect of Ang II on apoptosis in villous tip outgrowths was examined by immunostaining for CK-18 cleavage product (M30) and TUNEL staining $(n=3-5)$. Positively stained cytotrophoblasts were primarily located adjacent to the villous tip, with occasional apoptotic cells in the cell column (Fig. 7E). A very similar pattern was detected with TUNEL staining (Fig. 7F). Substitution of M30 antibody with MIgG or omission of terminal deoxynucleotidyl transferase (TdT) resulted in an absence of staining (insets, Fig. 7E and F). Ang II had no effect on apoptosis as monitored by either method (Fig. 7D, M30; TUNEL data not shown).

In villous explants, Ang II $\left(10^{-6} \mathrm{M}\right)$ significantly increased cytotrophoblast proliferative index compared with control levels as assessed by Ki67 immunostaining $(n=5-7 ; P<0.05)$ and BrdU incorporation $(n=3-10$; $P<0.01$; Fig. $8 \mathrm{~A}$ and B). Lower concentrations had no effect. Co-treatment with AGTR1/AGTR2 inhibitors non-significantly reduced the proliferative index $(n=3$, Fig. 8C). Apoptotic nuclei were detected primarily in the syncytiotrophoblast layer, but also in underlying cytotrophoblast cells. Ang II had no effect on the apoptotic index as assessed by immunostaining for 

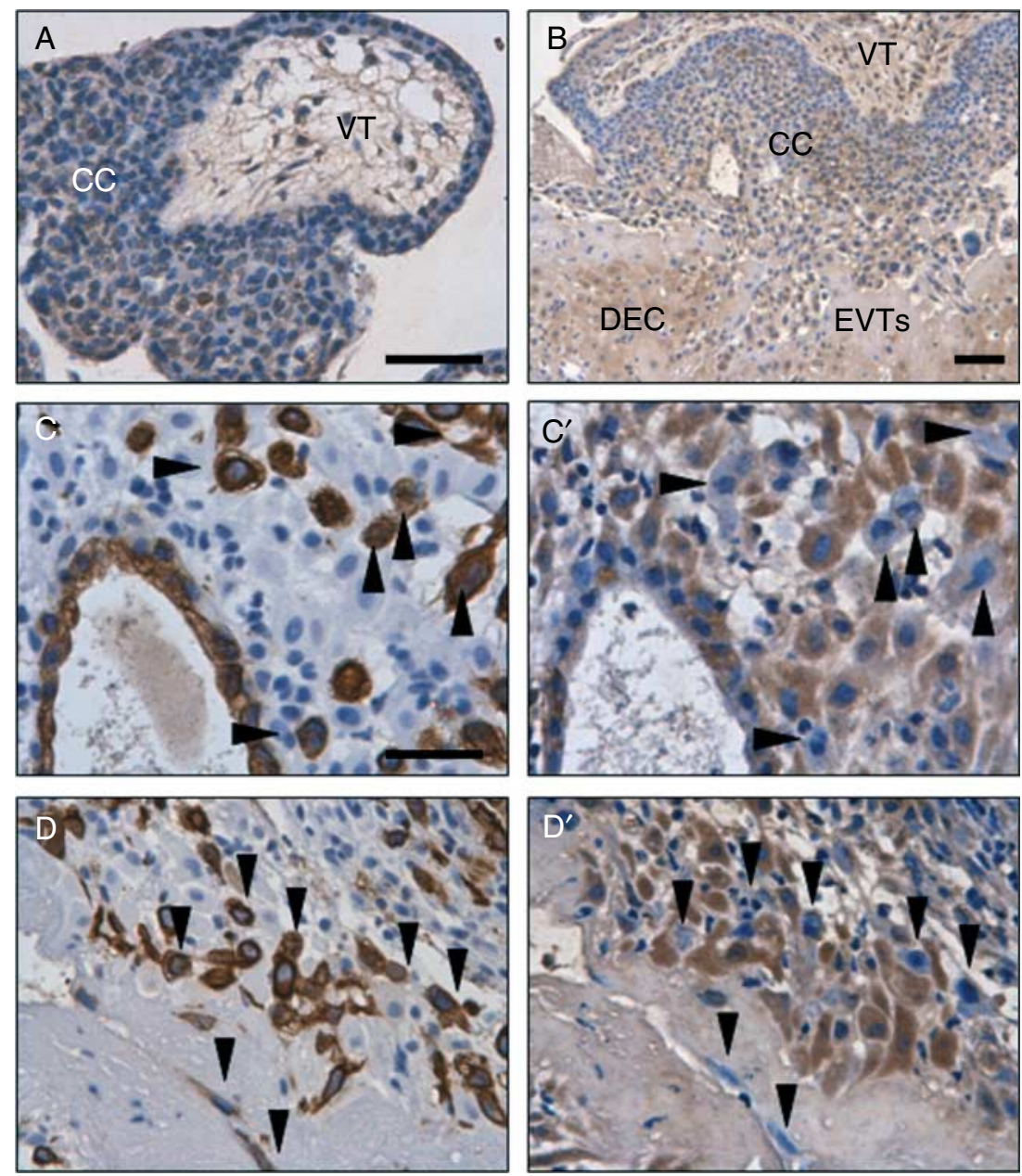

Figure 4 Immunolocalisation of AGTR2 at the maternal-fetal interface in early pregnancy. (A) Weak heterogeneous expression of AGTR2 in extravillous trophoblasts (EVTs) in floating cell column (CC), and (B) in anchoring column attached to decidua (DEC). Staining of serial sections with (C and D) cytokeratin-7 and ( $\mathrm{C}^{\prime}$ and $\mathrm{D}^{\prime}$ ) AGTR2 shows the absence of AGTR2 in extravillous trophoblasts (EVTs) invading the decidua. Representative EVTs in serial sections are indicated by arrowheads. Scale bar on (A) represents $50 \mu \mathrm{m}$ and on (B) $25 \mu \mathrm{m}$. Scale bar on (C) represents $25 \mu \mathrm{m}$ and refers to the images $(C)$ and $(D)$. cytokeratin M30 (Fig. 8D) or TUNEL staining (data not shown; $n=4-6$ placentas). Representative images of villous cytotrophoblast BrdU incorporation and TUNEL staining are shown in Fig. 8E and F.

\section{Discussion}

Until recently, immunohistochemical studies of Ang II receptors have been hampered by a lack of specific, high-affinity antibodies (Cooper et al. 1999, Laskowska et al. 2003, 2004, Thapa et al. 2004). We confirmed the presence of receptor AGTR2 in the first trimester human placenta, using molecular techniques, immunohistochemistry and western blotting. We have also described the expression of AGTR1 and AGTR2 in trophoblast subpopulations at the maternal-fetal interface, with AGTR1 primarily expressed by the differentiated trophoblasts:syncytiotrophoblast and cell column extravillous trophoblasts, and AGTR2 by proliferating villous cytotrophoblasts. AGTR2 is abundantly expressed in murine, porcine and bovine placenta (Grady et al. 1991, Nielsen et al. 1996, Schauser et al. 1998), and it is the predominant receptor present in human cycling endometrium and myometrium (Tsuzuki et al. 1994, Ahmed et al. 1995). However, previous reports in the literature of its expression in human placenta are conflicting (Cooper et al. 1999, Anton et al. 2008, Williams et al. 2010). In this study, AGTR2 transcripts were detected in 10/15 placental samples using SYBR green detection, while a signal was only detected in 4/15 samples using electrophoresis with ethidium bromide detection. The localisation of AGTR2 to villous cytotrophoblasts and Hofbauer cells, both of which are sparser per unit area of term placenta, may explain the failure of previous studies to detect the receptor in whole tissue placental homogenates later in gestation (Cooper et al. 1999, Anton et al. 2008). Its presence in human placenta is consistent with the observation of AGTR2dependent contraction of term chorionic plate artery vascular smooth muscle (Benoit et al. 2008) and low but significant AGTR2 inhibitory binding of radiolabelled Ang II to term placenta (Li et al. 1998).

Although the presence of AGTR1 in the human placenta has been previously reported (Li et al. 1998, Cooper et al. 1999) its actions remain elusive. Previous studies of AGTR1 localisation in placenta have shown diffuse cytoplasmic staining for the receptor and have 

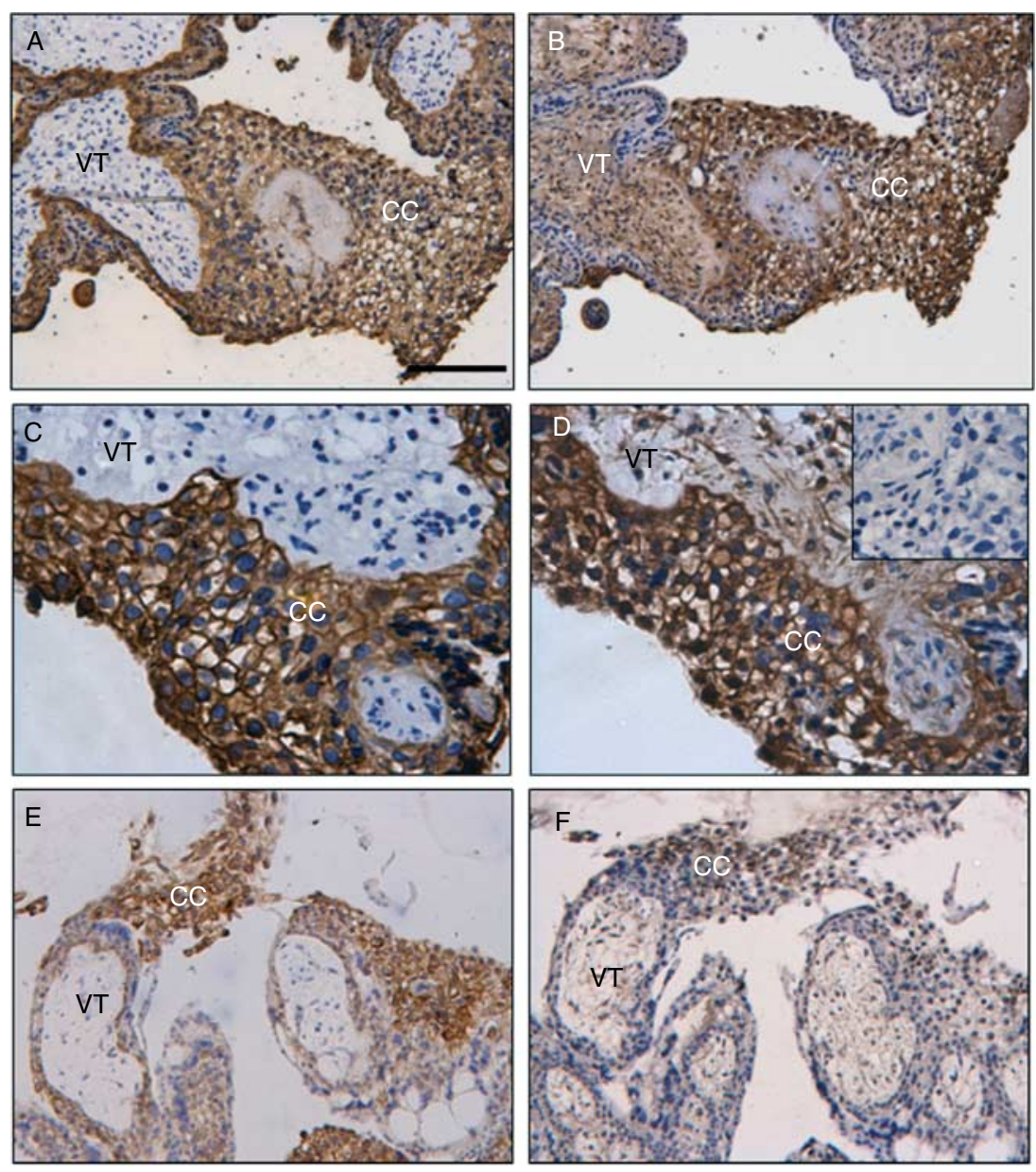

Figure 5 AGTR1 and AGTR2 expression in extravillous trophoblasts (EVT) generated by in vitro outgrowths from placental villous tips plated on collagen. (A, C and E) Cytokeratin-7 identifies EVT outgrowth in cell column (CC) from villous tip (VT). (B and D) EVTs stain strongly for AGTR1, with cell surface localisation shown in (D) at higher magnification. ( $D$, inset) Negative control showing absence of staining. (F) EVTs in the distal portion of the CC stain positively for AGTR2. Scale bar on (A) represents $50 \mu \mathrm{m}$ and also refers to image (B, E and F). Scale bar on (C) represents $25 \mu \mathrm{m}$ and also refers to the image $(\mathrm{D})$. either used antibodies at very high concentrations (Cooper et al. 1999, Laskowska et al. 2003, 2004) or used frozen tissue sections (Thapa et al. 2004), which have poor morphology, thereby making distinctions between individual cell types problematic. The specific localisation to the apical microvillous membrane of the syncytiotrophoblast is consistent with the inhibition of the system A amino acid transporter (Shibata et al. 2006), and the stimulation of placental lactogen and $17 \beta$-estradiol synthesis by exogenous Ang II (Kalenga et al. 1994, 1995). Occasional villous cytotrophoblasts immunopositive for AGTR1 may represent intermediate cells undergoing pre-fusion differentiation.

This study has demonstrated that high concentrations of Ang II significantly increase villous cytotrophoblast proliferation (assessed by BrdU incorporation and Ki67 immunostaining), but do not affect apoptosis (measured by CK-18 cleavage and TUNEL). Blockade of AGTR1 and AGTR2 together reduces cytotrophoblast proliferation index. The only previous report of Ang II actions on villous placental explants shows enhanced proliferation and reduced apoptosis, but does not describe the cell types involved (Williams et al. 2010). The discrepancy in the effect on apoptosis is likely to be due to the use of different methodologies and to the low sample number $(n=1-3)$ used by Williams et al. (2010). Together, these data support that Ang II has regulatory actions on first trimester placental development.

The distinct pattern of AGTR1 staining in the medial and distal cytotrophoblast columns and EVTs entering the decidua, but not in deeper interstitial, endovascular or intramural EVT, suggests that the AGTR1 receptor plays a role in early EVT differentiation. It appears that this receptor is acquired as cells exit the cell cycle after proliferating at the base of the columns. Uniform expression in columns in explant cultures is consistent with this view, because in this system cells exit the cell cycle after 24-36 h (Aplin et al. 1999). AGTR2 exhibits a similar expression profile in vivo and in vitro, although it appears to be less abundant. A previous study of the first trimester placental explants suggested that Ang II increased EVT outgrowth and the number of cells in the columns (Araki-Taguchi et al. 2008). Increased PAl1 and MMP2 mRNA, but absence of $\alpha 1$ integrin expression, was observed in the outgrowths. Our finding of increased $\mathrm{BrdU}$ incorporation with Ang II treatment support these 
A

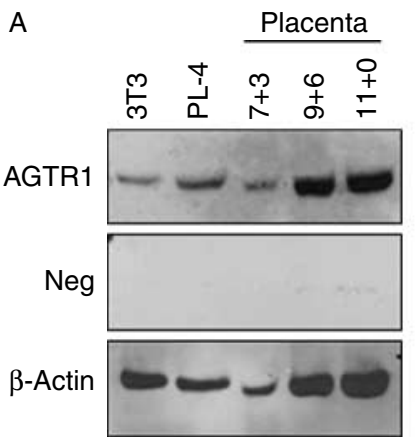

B

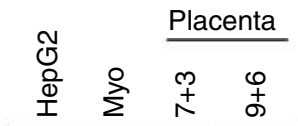

AGTR2

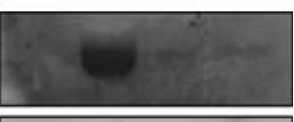

Neg

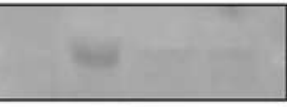

$\beta$-Actin

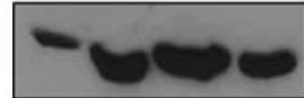

Figure 6 Western blotting for AGTR1 and AGTR2 on first trimester placental homogenates. (A) A single band of $44 \mathrm{kDa}$ corresponding to AGTR1 was detected in positive controls (3T3 and PL-4 cells) and in placental homogenates from 7 to 11 -weeks gestation. Pre-absorption with blocking peptide abolished band detection. $\beta$-Actin western blot included as a loading control. (B) A single band of $55 \mathrm{kDa}$ corresponding to AGTR2 was detected in myometrium. A faint signal was detected in placental homogenates from 7 to 9-weeks gestation. Pre-adsorption with blocking peptide abolished band detection.

observations. Moreover, the abolition of this effect by co-treatment with the AGTR1 and AGTR2 receptor blockers suggests that signalling through both the receptors is responsible for this effect, which is consistent with the co-expression of the receptors by cell column cytotrophoblasts. The striking absence of AGTR1 and AGTR2 in EVTs within the decidual stroma and spiral arteries indicates that Ang II is not involved in EVTmediated vascular remodelling. This is an important advance in the field and pinpoints the actions of Ang II in regulating EVT differentiation and entry into the decidua rather than in later invasion events. Decidua is a significant source of extra-renal Ang II production, and the co-expression of both AGTR1 and AGTR2 by decidual stromal cells suggests auto- and paracrine actions in regulating decidual and placental development and function (Morgan et al. 1997, Herse et al. 2007).

Genetic studies have suggested a role for AGTR1 in FGR and pre-eclampsia (Plummer et al. 2004, Tower et al. 2006). It is tempting to speculate that its transient upregulation in cell columns is a requirement for successful trophoblast invasion, and that its failure may play a role in the pathogenesis of pregnancy complications. Excessive or sustained stimulation of AGTR1 on EVTs, or activation of AGTR1 by auto-antibodies (Xia et al. 2003) may contribute to the reduced EVT colonisation of the decidua.

In summary, AGTR1 and AGTR2 expression occurs in distinct trophoblast populations. Antagonistic roles are well established, and our localisation data suggest that AGTR2 may be associated with the restriction of villous cytotrophoblast to a proliferative or progenitor status. Transient expression of AGTR1 in a minority of villous cytotrophoblasts, and in cell column cytotrophoblasts, is consistent with the roles in early differentiation in both lineages. The absence of AGTR1 and AGTR2 expression by interstitial and endovascular EVTs rules out the actions of Ang II in modulating EVT invasion or remodelling through these receptors. We report stimulatory action of Ang II on villous and extravillous trophoblast proliferation, which is inhibitory by dual blockade of AGTR1 and AGTR2. Ang II mediates angiogenesis (Khakoo et al. 2008) and inflammatory processes (Ruiz-Ortega et al. 2006) in other tissues, and Hofbauer cells, which express both the receptors, have diverse roles in placental vasculogenesis, angiogenesis (Demir et al. 2007) stromal fluid balance and immunological protection of the fetus (Demir \& Erbengi 1984, Castellucci \& Zaccheo 1989). Furthermore, interactions between Ang II and angiogenic factors, such as VEGF and transforming growth factor- $\beta$, are well described
A
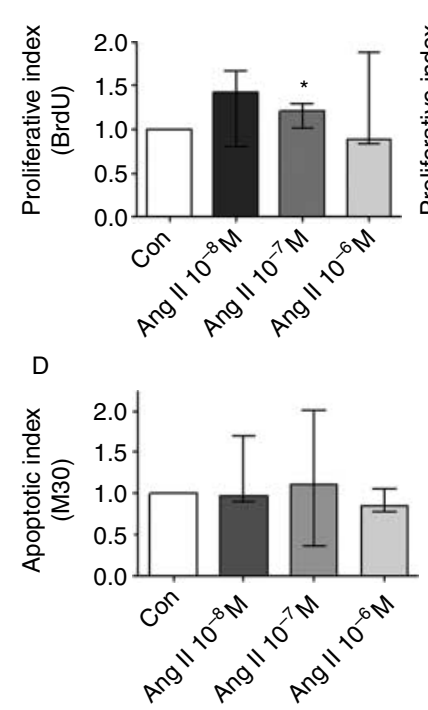

B

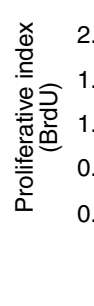

E

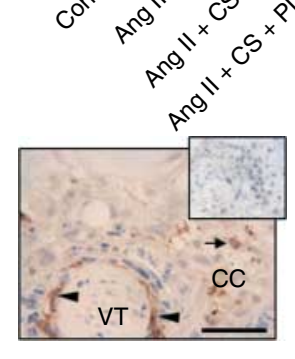

C

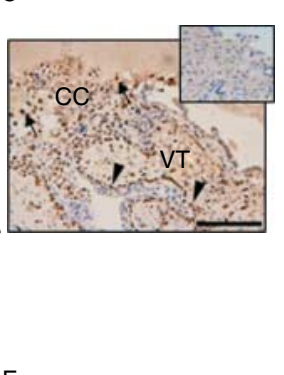

Figure 7 Effect of angiotensin II (Ang II) on cell column cytotrophoblast turnover in villous outgrowths. (A) Ang II $\left(10^{-7} \mathrm{M}\right)$ significantly stimulates $\mathrm{BrdU}$ incorporation into cell column cytotrophoblasts $\left({ }^{*} P<0.05\right)$. (B) Co-treatment with Ang II $\left(10^{-7} \mathrm{M}\right)$ and AGTR1 and AGTR2 inhibitors (CS, candesartan and PD, PD123319) in combination abolished the proliferative effect of Ang II. (C) Representative image of BrdU immunostaining in villous outgrowth (inset, negative control). (D) Ang II had no effect on apoptotic index as assessed by immunostaining for cytokeratin M30. Representative images of (E) cytokeratin M30 immunostaining and (F) Tunel staining in villous outgrowths. Insets show negative controls. VT, villous tip; CC, cell column. Arrowheads show positively stained cytotrophoblasts surrounding the villous tips. Arrows indicate positively stained cell column cytotrophoblasts. Scale bars represent $50 \mu \mathrm{m}(\mathrm{E})$ and $25 \mu \mathrm{m}(\mathrm{F})$. All graphical data are fold change from control and are shown as median and interquartile ranges. 


$$
\text { A }
$$
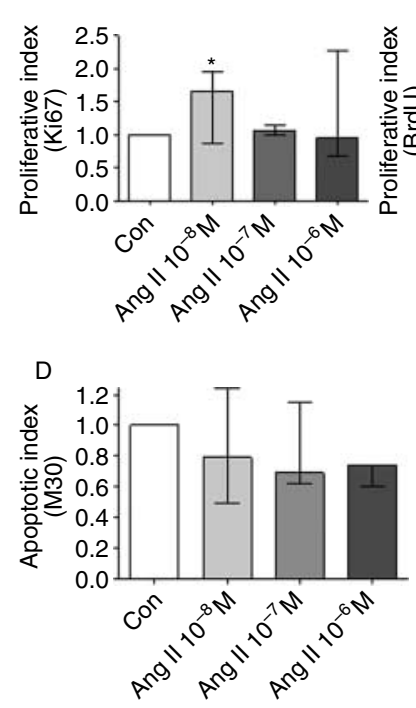

B

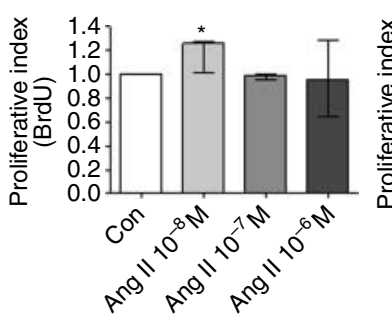

E

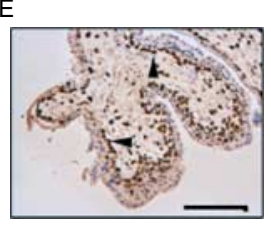

C

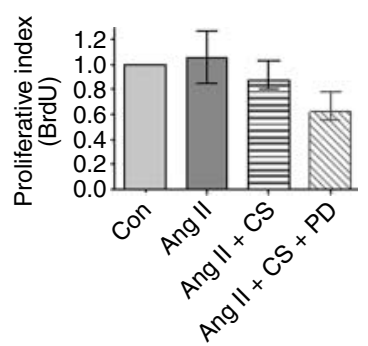

F

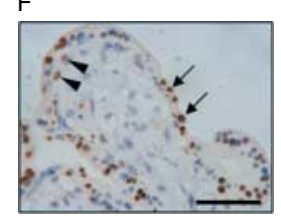

Figure 8 Effect of angiotensin II (Ang II) on cytotrophoblast cell turnover in first trimester placental explants. Proliferative index assessed using (A) Ki67 and (B) BrdU incorporation. Ang II $\left(10^{-6} \mathrm{M}\right)$ stimulated proliferation compared with control $(* P<0.05)$. (C) Co-treatment with Ang II $\left(10^{-7} \mathrm{M}\right)$, AGTR1 (CS, candesartan) and AGTR2 (PD, PD123319) inhibitors resulted in a non-significant decrease in proliferative index. (D) Apoptotic index assessed by immunostaining for cytokeratin M30. Representative images of explant (E) BrdU immunostaining and (F) Tunel staining. Arrowheads show positively stained villous cytotrophoblasts. Arrows indicate positively stained syncytiotrophoblast nuclei. Scale bars represent $50 \mu \mathrm{m}(\mathrm{C})$ and $25 \mu \mathrm{m}$ (E and F). All graphical data are fold change from control and are shown as median and interquartile ranges.
(Kagami et al. 1994, Chua et al. 1998, Tower et al. 2005). Defining the functions of Ang II in pregnancy pathologies and the mechanisms of regulation of receptor expression in placenta remain future challenges.

\section{Materials and Methods}

\section{Tissue collection}

First trimester placental and decidual samples $(n=25)$ were collected from women undergoing elective surgical and medical termination of pregnancy between 7 and 12 weeks gestation. Written informed consent was obtained from all women and this study was approved by the Central Manchester Regional Ethics Committee (03/CM/31). Tissue samples were obtained within 30 min of surgery and macroscopically dissected to separate villous placenta and maternal decidua. Portions of each $\left(\sim 0.5-1 \mathrm{~cm}^{2}\right)$ were fixed in $10 \%$ neutral buffered formalin for either $30 \mathrm{~min}$ or $24 \mathrm{~h}$ at $4{ }^{\circ} \mathrm{C}$, prior to thorough washing in Tris-buffered saline (TBS) and routine paraffin embedding. In all, $5 \mu \mathrm{m}$ sections were cut on to poly-L-lysine (Sigma)-coated microscope slides for immunohistochemistry. A further portion of the placenta was immersed in RNALater (Applied Biosystems, Foster City, CA, USA), prior to RNA extraction using Absolutely RNA RT-PCR Mini prep kit (Stratagene, La Jolla, CA, USA), including a DNase step, according to the manufacturer's instructions.

\section{Real-time PCR}

RNA was quantified using the Ribogreen assay (Invitrogen Ltd), with reference to rRNA standards. cDNA was generated from 500 ng RNA using StrataScript First-Strand Synthesis System (Stratagene) following the manufacturer's protocol.

As previous literature suggested that detection of the AGTR2 receptor mRNA may be problematic (Cooper et al. 1999), real-time PCR using SYBR green was conducted as this detects lower levels of expression compared with the previously conducted ethidium visualisation. Primers (forward AT2MX1, 5'-GCT ATG GGA AGA ACA GGA TAA C-3', and reverse AT2MX2, 5'-TCC TTC ACG GTC CAG TTA C-3') were designed using Beacon Designer (Premier Biosoft, Palo Alto, CA, USA) and were located within exon 3 of the AGTR2 receptor gene. Primers were Blast searched (http://www.ncbi.nlm.nih.gov/ blast/Blast). The presence of splice variants (Wharton et al. 1997, Nishimura et al. 1999) and the small sizes of exons 1 and 2 meant that it was not possible to design exon-spanning primers. Thus, negative controls of extracted, but not reverse transcribed, RNA samples were subjected to the PCR protocol to exclude genomic DNA contamination. Realtime PCR was conducted on the MX4000 thermal cycler (Stratagene) using Brilliant QPCR SYBR Green QPCR Master Mix (Stratagene). Samples underwent denaturation at $95^{\circ} \mathrm{C}$ for $10 \mathrm{~min}$, followed by 40 cycles at $95{ }^{\circ} \mathrm{C}$ for $30 \mathrm{~s}, 56{ }^{\circ} \mathrm{C}$ for $1 \mathrm{~min}$ and $72{ }^{\circ} \mathrm{C}$ for $30 \mathrm{~s}$, followed by the generation of the melting curve at $95{ }^{\circ} \mathrm{C}$ for $1 \mathrm{~min}$ and $56^{\circ} \mathrm{C}$ for $30 \mathrm{~s}$. All PCRs were conducted in duplicate with negative controls on the same plate. cDNA generated from myometrium was used as a positive control. PCR products were subsequently subjected to $1 \%$ agarose gel electrophoresis using ethidium bromide visualisation.

\section{Immunohistochemistry for AGTR1 and AGTR2 in villous placenta}

AGTR1 and AGTR2 subtypes were immunolocalised in $5 \mu \mathrm{m}$ sections of placenta. For AGTR1, sections of the placental tissue fixed for $24 \mathrm{~h}$ were dewaxed in xylene and rehydrated through descending grades of ethanol. Endogenous peroxidise activity was inhibited by treatment with $3 \%$ hydrogen peroxide (BDH Chemical Ltd, Poole, UK) prior to application of a nonimmune block (10\% normal swine serum (Sigma), 2\% human serum ('in house') and $0.1 \%$ Tween-20 (Bio-Rad) in TBS) for $30 \mathrm{~min}$. The primary antibody, rabbit polyclonal antibody 
directed against the $\mathrm{N}$-terminal extracellular domain of human AGTR1 (sc-1173; Santa Cruz Biotechnology, Santa Cruz, CA USA), was diluted to $5 \mu \mathrm{g} / \mathrm{ml}$ and applied to sections overnight at $4{ }^{\circ} \mathrm{C}$. Thereafter, antibody binding was detected by the sequential application of biotinylated swine anti-rabbit IgGs (Dako, Ely, UK) and avidin-peroxidase conjugate (Sigma). The chromogen diaminobenzidine (Sigma) was applied for 5 min, followed by counterstaining with Harris' haematoxylin and differentiation with acid alcohol. Sections were dehydrated through ascending grades of ethanol, cleared with xylene and mounted with DPX (BDH).

For AGTR2, sections of the placental tissue fixed for $30 \mathrm{~min}$ were used. A similar protocol was followed, with the following exceptions. The non-immune block contained rabbit, rather than swine, serum. The primary antibody was a goat polyclonal antibody directed against the $\mathrm{N}$-terminal extracellular domain of human AGTR2 (sc-7421, Santa Cruz Biotechnology) diluted to $7 \mu \mathrm{g} / \mathrm{ml}$. Secondary antibody was biotinylated rabbit antigoat IgG (Dako).

Rat adult and fetal kidney were used as positive controls, and antibodies were pre-adsorbed with a fivefold excess of blocking peptide to serve as a negative control. Both antibodies have previously been used to immunolocalise AGTR1 and AGTR2 receptors in human colonic mucosa (Hirasawa et al. 2002) and rat kidney (Miyata et al. 1999).

\section{Identification of AGTR1 and AGTR2 in EVTs}

To identify decidua basalis (containing invasive EVTs), immunohistochemistry was performed for CK-7. A similar protocol as described above was used with the following alterations. Antigen retrieval was performed by microwaving for $2 \times 5 \mathrm{~min}$ in $0.01 \mathrm{M}$ sodium citrate buffer $(\mathrm{pH}$ 6.0). The non-immune block contained $10 \%$ normal goat serum (Sigma), $2 \%$ human serum and $0.1 \%$ Tween-20 in TBS. The primary antibody, mouse monoclonal directed against CK-7 (Dako), was diluted to $0.5 \mu \mathrm{g} / \mathrm{ml}$ in non-immune block.

Owing to differences in fixation and antigen retrieval methods for all the antibodies, it was not possible to use dual immunohistochemistry to investigate co-localisation of CK-7 with AGTR1 and AGTR2. Instead, $5 \mu \mathrm{m}$ serial sections were immunostained for CK-7 and AGTR1 or AGTR2, using identical protocols as described for villous placenta. These experiments were performed on decidua basalis samples $(n=7)$ exhibiting endovascular and interstitial EVT invasion, identified by prior CK-7 immunostaining.

\section{Villous tip outgrowths}

First trimester placentae were washed in warmed 1:1 mix of DMEM and Ham's F12 (DMEM/F12, Invitrogen), containing $1 \%$ penicillin, streptomycin and L-glutamine (PSG, Sigma) and terminal portions of villi with trophoblast cell columns were selected and separated under a dissecting microscope as previously described (Aplin et al. 1999). Villous tips were seeded onto collagen gels prepared in advance using $1 \mathrm{ml}$ of rat tail collagen ( $4 \mathrm{mg} / \mathrm{ml}$; BD Biosciences, Oxford, UK) mixed with $50 \mu \mathrm{l}$ of culture medium, followed by $100 \mu \mathrm{l}$ of $7.5 \%$ $\mathrm{NaHCO}_{3}$. As the collagen polymerised, $100 \mu \mathrm{l}$ was aliquotted into each well of a 24 -well culture plate and left to set at $37^{\circ} \mathrm{C}$ for $30 \mathrm{~min}$. One villous tip was transferred to the gel surface using fine forceps, surrounded by culture medium and allowed to attach overnight at $37{ }^{\circ} \mathrm{C}$, under $3 \% \mathrm{O}_{2}$. Attachment was assessed $\sim 16 \mathrm{~h}$ later, by the appearance of radial stress lines in the collagen gel, at which point $1 \mathrm{ml}$ of medium was added to cover each villous tip. Villi were left in culture for $48 \mathrm{~h}$, then fixed in $10 \%$ neutral buffered formalin for $24 \mathrm{~h}$, processed to paraffin blocks and cut sections were stained for CK-7, AGTR1 and AGTR2 as described above.

\section{Microscopy}

A Leitz Dialux 22 microscope was used in conjunction with a QI Cam Fast 1394 camera and Image Proplus 6.0 imaging system for photography and analysis of immunostaining.

\section{Western blotting}

To confirm the specificity of the antibodies and the expression of AGTR1 and AGTR2 protein by the first trimester placenta, western blotting analysis was performed on first trimester placental lysates, with appropriate positive controls (AGTR1: 3T3 and PL-4 cells; AGTR2: myometrium and HepG2 cells). Placental tissue was washed in cold PBS then homogenised on ice in RIPA buffer (Tris $50 \mathrm{mM}, \mathrm{NaCl} 150 \mathrm{mM}$, SDS 0.1\%, sodium deoxycholate $0.5 \%$, NP40 1\%) with the addition of $10 \mu \mathrm{l} / 10 \mathrm{ml}$ protease inhibitor cocktail (set 1; VWR, East Grinstead, UK). Samples were centrifuged at $17600 \mathrm{~g}$, at $4{ }^{\circ} \mathrm{C}$ for $10 \mathrm{~min}$ and the supernatant was stored at $-80^{\circ} \mathrm{C}$. Protein content was determined using the standardised Commercial Bradford Assay (Bio-Rad).

For AGTR1, $15 \mu \mathrm{g}$ placental lysate were reduced using $\beta$-mercaptoethanol prior to loading on a $12 \%$ polyacrylamide gel and were separated using SDS-PAGE at $200 \mathrm{~V}$ for $3.5 \mathrm{~h}$. For AGTR2, $60 \mu \mathrm{g}$ placental lysate were reduced using $\beta$-mercaptoethanol and heated at $95{ }^{\circ} \mathrm{C}$ for $5 \mathrm{~min}$, then stored overnight at $-20{ }^{\circ} \mathrm{C}$ prior to loading and were subjected to electrophoresis like AGTR1. Proteins were then transferred to a nitrocellulose membrane (Hybond ECL, Amersham Biosciences) using electro-transfer. Membranes were blocked in $3 \% \mathrm{BSA}$ for $2 \mathrm{~h}$ at room temperature, then probed with primary antibodies for AGTR1 (sc-1173, Santa Cruz Biotechnology, $0.2 \mu \mathrm{g} / \mathrm{ml}$ ) and AGTR2 (sc-7421, Santa Cruz Biotechnology, $1 \mu \mathrm{g} / \mathrm{ml}$ ) overnight at $4{ }^{\circ} \mathrm{C}$. After thorough washing in TBS-Tween (TBS 0.05\% Tween-20), membranes were incubated with HRP-conjugated secondary antibodies $(0.2 \mu \mathrm{g} / \mathrm{ml}$, Dako) for $1.5 \mathrm{~h}$ at room temperature. After further washes, bands were visualised on photosensitive film (Amersham Biosciences) using ECL reagents (ECL1: $2.5 \mathrm{mM}$ luminol, $1.1 \mathrm{mM}$ p-coumaric acid, $0.1 \mathrm{M}$ Tris $\mathrm{pH}$ 8.5; ECL2: $0.02 \%$ hydrogen peroxide, $0.1 \mathrm{M}$ Tris $\mathrm{pH} 8.5$ ). Antibody specificity was verified by pre-adsorption with $5 \times$ peptide block overnight at $4{ }^{\circ} \mathrm{C}$ prior to applying to the membranes. To confirm protein loading, membranes were stripped in $62.5 \mathrm{mM}$ Tris- $\mathrm{HCl}, 2 \% \mathrm{w} / \mathrm{v}$ SDS and $100 \mathrm{mM} \beta$-mercaptoethanol $\mathrm{pH} 6.7$ for $40 \mathrm{~min}$ by agitating at $50{ }^{\circ} \mathrm{C}$ and reprobed using mouse $\mathrm{MAB}$ to $\beta$-actin (Sigma, $0.2 \mu \mathrm{g} / \mathrm{ml}$ ). 


\section{Effect of Ang II on villous and extravillous trophoblast cell turnover}

Villous explants $\left(\sim 3 \mathrm{~mm}^{3}, n=10\right.$ placentas $)$ were dissected and cultured in DMEM/F12 containing 1\% PSG. After $24 \mathrm{~h}$, Ang II $\left(10^{-6}-10^{-8} \mathrm{M}\right)$ and $100 \mu \mathrm{M} \mathrm{BrdU}$ were added in culture medium and explants were cultured for a further $48 \mathrm{~h}$. Villous outgrowths ( $n=10$ placentas) were generated as above, with Ang II $\left(10^{-6}-10^{-8} \mathrm{M}\right)$ treatment from $18 \mathrm{~h}$ for a further $72 \mathrm{~h}$. In a subgroup of explants and outgrowths, selective AGTR1 (candesartan, $10^{-6} \mathrm{M}$; Takeda Pharmaceuticals, Osaka, Japan) and AGTR2 (PD123319, $10^{-6}$ M; Pfizer Ltd, Sandwich, UK) inhibitors were added in the presence and absence of Ang II (10 ${ }^{-7} \mathrm{M} ; n=3$ placentas).

At the end of the culture period, explants and outgrowths were fixed in $10 \%$ neutral buffered formalin, wax embedded and subjected to immunohistochemistry for proliferating (Ki67, BrdU) and apoptotic cells (cytokeratin M30). A similar protocol was used as described for AGTR1/AGTR2 with the following exceptions. To detect proliferating cells, tissue sections were microwaved in $0.01 \mathrm{M}$ sodium citrate $(\mathrm{pH}$ 6.0) for $10 \mathrm{~min}$, followed by incubation in a non-immune block comprising $10 \%$ normal goat serum, $2 \%$ human serum and $0.1 \%$ Tween20 in TBS. Mouse monoclonal anti-Ki67 (Dako) was applied at $0.6 \mu \mathrm{g} / \mathrm{ml}$. Proliferation was also assessed by BrdU incorporation; sections were pretreated with $2 \mathrm{M} \mathrm{HCl}$ and $0.1 \%$ trypsin at $37{ }^{\circ} \mathrm{C}$, prior to application of monoclonal anti-BrdU (Sigma) diluted to $3 \mu \mathrm{g} / \mathrm{ml}$ in $5 \%$ BSA. Apoptosis was detected by immunostaining for the cytokeratin M30 neoepitope using a monoclonal anti-M30 (Roche) at $1 \mu \mathrm{g} / \mathrm{ml}$. In all cases, the secondary antibody was biotinylated with goat anti-mouse IgG (Dako). Negative controls were performed by substitution of primary antibody with non-immunised mouse IgG. TUNEL staining was performed using the In Situ Cell Death Detection kit with peroxidase detection (Roche) as described previously (Heazell et al. 2008) on a subgroup of explants and outgrowths $(n=3-5)$ to confirm the apoptosis data. Application of dUTP in the absence of TdT was performed as a negative control.

\section{Quantification of cell turnover}

Ten fields of view of each tissue section were imaged. Cells positive for Ki67, BrdU and M30 were manually counted and the total nuclear count was quantified using image analysis software or by manual counting. The proliferative/apoptotic index is a ratio of the number of positive cells over the total nuclear count. All data were expressed as fold change from control to overcome inherent variability in the basal proliferation/apoptotic index. Statistical analyses were performed using Graphpad Prism, using Wilcoxon signed rank tests to determine the significance of changes in cell turnover compared with basal levels.

\section{Declaration of interest}

The authors declare that there is no conflict of interest that could be perceived as prejudicing the impartiality of the research reported.

\section{Funding}

This work was supported by the University of Manchester Research Support Fund and Stepping Stones Fellowship. The Maternal and Fetal Health Research Group is supported by the Manchester Academic Health Sciences Centre (MAHSC) and the NIHR Manchester Biomedical Research Centre.

\section{Author contribution statement}

$\mathrm{C} L$ Tower and $\mathrm{R} L$ Jones were involved in the study design, analysis, manuscript drafting and critical discussion. S Lui, N R Charlesworth and S D Smith contributed to study execution, analysis and critical discussion. J D Aplin contributed to data analysis, critical discussion and manuscript drafting. All authors approved the final draft of the manuscript.

\section{Acknowledgements}

We would like to acknowledge the assistance of Alisha Varma and Claudia Popescu in various aspects of this study. Thanks are due to Takeda Pharmaceuticals and Pfizer Ltd for their kind gifts of AGTR1 and AGTR2 inhibitors. We would also like to thank the nurses and theatre staff at St Mary's Hospital for their invaluable role in patient recruitment and placental tissue collection. Thanks are also due to Dr Mark Dilworth for providing mouse kidney samples.

\section{References}

AbdAlla S, Lother H, Abdel-tawab AM \& Quitterer U 2001 The angiotensin II $\mathrm{AT}_{2}$ receptor is an $\mathrm{AT}_{1}$ receptor antagonist. Journal of Biological Chemistry 276 39721-39726. (doi:10.1074/jbc.M105253200)

Ahmed A, Li XF, Shams M, Gregory J, Rollason T, Barnes NM \& Newton JR 1995 Localization of the angiotensin II and its receptor subtype expression in human endometrium and identification of a novel highaffinity angiotensin II binding site. Journal of Clinical Investigation 96 848-857. (doi:10.1172/JCl118131)

Anton L, Merrill DC, Neves LA, Stovall K, Gallagher PE, Diz DI, Moorefield C, Gruver C, Ferrario CM \& Brosnihan KB 2008 Activation of local chorionic villi angiotensin II levels but not angiotensin (1-7) in preeclampsia. Hypertension 51 1066-1072. (doi:10.1161/HYPERTENSIONAHA.107.103861)

Aplin JD, Haigh T, Jones CJ, Church HJ \& Vicovac L 1999 Development of cytotrophoblast columns from explanted first-trimester human placental villi: role of fibronectin and integrin $\alpha 5 \beta 1$. Biology of Reproduction 60 828-838. (doi:10.1095/biolreprod60.4.828)

Araki-Taguchi M, Nomura S, Ino K, Sumigama S, Yamamoto E, Kotani-Ito T, Hayakawa H, Kajiyama H, Shibata K, Itakura A et al. 2008 Angiotensin II mimics the hypoxic effect on regulating trophoblast proliferation and differentiation in human placental explant cultures. Life Sciences $\mathbf{8 2}$ 59-67. (doi:10.1016/j.Ifs.2007.10.017)

Benoit C, Gu Y, Zhang Y, Alexander JS \& Wang Y 2008 Contractility of placental vascular smooth muscle cells in response to stimuli produced by the placenta: roles of ACE vs. non-ACE and AT1 vs. AT2 in placental vessel cells. Placenta 29 503-509. (doi:10.1016/j.placenta. 2008.03.002)

Castellucci M \& Zaccheo D 1989 The Hofbauer cells of the human placenta: morphological and immunological aspects. Progress in Clinical and Biological Research 296 443-451.

Chua C, Hamdy R \& Chua B 1998 Upregulation of vascular endothelial growth factor by angiotensin II in rat heart endothelial cells. Biochimica et Biophysica Acta 1401 187-194. 
Cooper A, Robinson G, Vinson G, Cheung W \& Broughton Pipkin F 1999 The localization and expression of the renin-angiotensin system in the human placenta throughout pregnancy. Placenta 20 467-474. (doi:10.1053/plac.1999.0404)

Demir R \& Erbengi T 1984 Some new findings about Hofbauer cells in the chorionic villi of the human placenta. Acta Anatomica 119 18-26.

Demir R, Seval Y \& Huppertz B 2007 Vasculogenesis and angiogenesis in the early human placenta. Acta Histochemica 109 257-265. (doi:10.1016/j.acthis.2007.02.008)

Dinh DT, Frauman AG, Johnston CI \& Fabiani ME 2001 Angiotensin receptors: distribution, signalling and function. Clinical Science $\mathbf{1 0 0}$ 481-492. (doi:10.1042/CS20000263)

De Gasparo M, Catt K, Inagami T, Wright J \& Unger T 2000 International Union of Pharmacology. XXIII. The angiotension II receptors. Pharmacological Reviews 52 415-472.

Grady EF, Sechi LA, Griffin CA, Schambelan M \& Kalinak JE 1991 Expression of AT2 receptors in the developing rat fetus. Journal of Clinical Investigation 88 921-933. (doi:10.1172/JCl115395)

Heazell AE, Lacey HA, Jones CJ, Huppertz B, Baker PN \& Crocker IP 2008 Effects of oxygen on cell turnover and expression of regulators of apoptosis in human placental trophoblast. Placenta 29 175-186. (doi:10.1016/j.placenta.2007.11.002)

Herse F, Dechend R, Harsem NK, Wallukat G, Janke J, Qadri F, Hering L, Muller DN, Luft FC \& Staff AC 2007 Dysregulation of the circulating and tissue-based renin-angiotensin system in preeclampsia. Hypertension 49 604-611. (doi:10.1161/01.HYP.0000257797.49289.71)

Hirasawa K, Sato Y, Hosoda Y, Yamamoto T \& Hanai H 2002 Immunohistochemical localization of angiotensin II receptor and local renin-angiotensin system in human colonic mucosa. Journal of Histochemistry and Cytochemistry $\mathbf{5 0}$ 275-282.

Hosokawa T, Howard RB \& Maguire MH 1985 Conversion of angiotensin I to angiotensin II in the human foetoplacental vascular bed. British Journal of Pharmacology 84 237-241.

Kagami S, Border WA, Miller DE \& Noble NA 1994 Angiotensin II stimulates extracellular matrix protein synthesis through induction of transforming growth factor $\beta$ expression in rat glomerular mesangial cells. Journal of Clinical Investigation 93 2431-2437. (doi:10.1172/ JCl117251)

Kalenga M, de Gasparo M, Thomas K \& De Hertogh R 1994 Angiotensin II induces human placental lactogen and pregnancy - specific $\beta 1$ glycoprotein secretion via and angiotensin AT1 receptor. European Journal of Pharmacology 268 231-236. (doi:10.1016/0922-4106(94) 90193-7)

Kalenga MK, De Gasparo M, Thomas K \& De Hertogh R 1995 Angiotensin II stimulates estradiol secretion from human placental explants through AT1 receptor activation. Journal of Clinical Endocrinology and Metabolism 80 1233-1237. (doi:10.1210/jc.80.4.1233)

Khakoo AY, Sidman RL, Pasqualini R \& Arap W 2008 Does the reninangiotensin system participate in regulation of human vasculogenesis and angiogenesis? Cancer Research 68 9112-9115. (doi:10.1158/00085472.CAN-08-0851)

Laskowska M, Leszczynska-Gorzelak B \& Oleszczuk J 2003 Placental angiotensin II receptor AT1R in normotensive patients and its correlation between infant birth weight. European Journal of Obstetrics, Gynecology, and Reproductive Biology 109 166-170. (doi:10.1016/ S0301-2115(03)00079-4)

Laskowska M, Laskowska K, Vinson G, Leszczynska-Gorzelak B \& Oleszczuk J 2004 Evaluation of placental angiotensin type 1 receptors in women with hypertension during pregnancy. Journal of Maternal-Fetal and Neonatal Medicine 16 223-229. (doi:10.1080/jmf. 16.4.223.229)

Le Noble FAC, Kekking JWM, Van Staaten HWM, Slaaf DW \& Struyker Boudier HAJ 1991 Angiotensin II stimulates angiogenesis in the chorio-allantoic membrane of the chick embryo. European Journal of Pharmacology 195 305-306. (doi:10.1016/0014-2999(91)90552-2)

Li X, Shams M, Zhu J, Khaliq A, Wilkes M, Whittle M, Barnes N \& Ahmed A 1998 Cellular localization of AT1 sub 1 receptor mRNA and protein in normal placenta and its reduced expression in intrauterine growth restriction: angiotensin II stimulates the release of vasorelaxants. Journal of Clinical Investigation 101 442-454. (doi:10.1172/JCI119881)
Miyata N, Park F, Li XF \& Cowley AW Jr 1999 Distribution of angiotensin AT1 and AT2 receptor subtypes in the rat kidney. American Journal of Physiology 277 F437-F446.

Morgan T, Craven C, Nelson L, Lalouel J-M \& Ward K 1997 Angiotensinogen T235 expression is elevated in decidual spiral arteries. Journal of Clinical Investigation 100 1406-1415. (doi:10.1172/ JCI119661)

Nielsen AH, Winther H, Dantzer V \& Poulsen K 1996 High densities of angiotensin II subtype 2 (AT2) receptors in the porcine placenta and fetal membranes. Placenta 17 147-153. (doi:10.1016/S0143-4004 (96)80007-5)

Nishimura $H$, Yerkes E, Hohenfellner K, Miyazaki Y, Ma J, Hunley TE, Yoshida H, Ichiki T, Threadgill D, Phillips JA et al. 1999 Role of the angiotensin type 2 receptor gene in anomalies of the kidney and urinary tract, CAKUT, of mice and men. Molecular Cell 3 1-10. (doi:10.1016/ S1097-2765(00)80169-0)

Ozono R, Wang ZQ, Moore AF, Inagami T, Siragy HM \& Carey RM 1997 Expression of the subtype 2 angiotensin (AT2) receptor protein in rat kidney. Hypertension 30 1238-1246.

Peach MJ 1981 Molecular actions of angiotensin. Biochemical Pharmacology 30 2745-2751. (doi:10.1016/0006-2952(81)90410-X)

Plummer S, Tower C, Alonso P, Morgan L, Baker P, Broughton-Pipkin F \& Kalsheker N 2004 Haplotypes of the angiotensin II receptor genes in women with normotensive pregnancy and women with preeclampsia. Human Mutation 24 14-20. (doi:10.1002/humu.20050)

Ruiz-Ortega M, Esteban V, Ruperez M, Sanchez-Lopez E, RodriguezVita J, Carvajal G \& Egido J 2006 Renal and vascular hypertensioninduced inflammation: role of angiotensin II. Current Opinion in Nephrology and Hypertension 15 159-166. (doi:10.1097/01.mnh. 0000203190.34643.d4)

Schauser KH, Nielsen AH, Winther H, Dantzer V \& Poulsen K 1998 Autoradiographic localization and characterization of angiotensin II receptors in the bovine placenta and fetal membranes. Biology of Reproduction 59 684-692. (doi:10.1095/biolreprod59.3.684)

Shaw KJ, Do YS, Kjos S, Anderson PW, Shinagawa T, Dubeau L \& Hsueh W 1989 Human decidua is a major source of renin. Journal of Clinical Investigation 83 2085-2092. (doi:10.1172/ JCI114121)

Shibata E, Powers RW, Rajakumar A, von Versen-Hoynck F, Gallaher MJ, Lykins DL, Roberts JM \& Hubel CA 2006 Angiotensin II decreases system A amino acid transporter activity in human placental villous fragments through AT1 receptor activation. American Journal of Physiology. Endocrinology and Metabolism 291 E1009-E1016. (doi:10. 1152/ajpendo.00134.2006)

Thapa L, He C \& Chen H 2004 Study on the expression of angiotensin II (ANGII) receptor subtype $1\left(\mathrm{AT}_{1} \mathrm{R}\right)$ in the placenta of pregnancyinduced hypertension. Placenta 25 637-641. (doi:10.1016/j.placenta. 2004.01.026)

Tower CL, Chappell SL, Morgan K, Kalsheker N, Baker PN \& Morgan LJ 2005 Transforming growth factor $\beta 1$ regulates angiotensin II type I receptor gene expression in the extravillous trophoblast cell line SGHPL-4. Molecular Human Reproduction 11 847-852. (doi:10.1093/ molehr/gah242)

Tower C, Chappell S, Acharya M, Crane R, Szolin S, Symonds L, Chevins H, Kalsheker N, Baker P \& Morgan L 2006 Altered transmission of maternal angiotensin II receptor haplotypes in fetal growth restriction. Human Mutation 27 138-144. (doi:10.1002/humu.20265)

Tsuzuki S, Ichiki T, Nakakubo H, Kitami Y, Guo DF, Shirai H \& Inagami T 1994 Molecular cloning and expression of the gene encoding human angiotensin II type 2 receptor. Biochemical and Biophysical Research Communications 200 1449-1454. (doi:10.1006/ bbrc.1994.1613)

Wharton J, Morgan K, Rutherford RA, Catravas JD, Chester A, Whitehead BF, De Leval MR, Yacoub MH \& Polak JM 1997 Differential distribution of angiotensin $\mathrm{AT}_{2}$ receptors in the normal and failing human heart. Journal of Pharmacology and Experimental Therapeutics 284 323-336.

Williams PJ, Mistry HD, Innes BA, Bulmer JN \& Pipkin FB 2010 Expression of AT1R, AT2R and AT4R and their roles in extravillous trophoblast invasion in the human. Placenta 31 448-455. (doi:10.1016/j.placenta. 2010.02.014) 
Xia Y, Wen HY \& Kellems RE 2002 Angiotensin II inhibits trophoblast invasion through AT1 receptor activation. Journal of Biological Chemistry 277 24601-24608. (doi:10.1074/jbc.M201369200)

Xia Y, Wen H, Bobst S, Day M-C \& Kellems R 2003 Maternal autoantibodies from preeclamptic patients activate angiotensin receptors on human trophoblast cells. Journal of the Society for Gynecologic Investigation 10 82-93. (doi:10.1016/S1071-5576(02)00259-9)

Xia Y, Zhou CC, Ramin SM \& Kellems RE 2007 Angiotensin receptors, autoimmunity, and preeclampsia. Journal of Immunology 179 3391-3395.
Yamada T, Horiuchi M \& Dzau VJ 1996 Angiotensin II type 2 receptor mediates programmed cell death. PNAS 93 156-160. (doi:10.1073/pnas. 93.1.156)

Received 14 July 2010

First decision 12 August 2010

Accepted 13 September 2010 